Journal of Teacher Education for Sustainability, vol. 19, no. 1, pp. 129-146, 2017

\title{
Value Education in Estonian Preschool Child Care Institutions
}

\author{
Pärje Ülavere and Anu Tammik \\ Tallinn University, Estonia
}

\begin{abstract}
For systematic implementation of value education in educational institutions, the national programme "Values Development in Estonian Society 2009-2013" (Ministry of Education and Research, 2009) was prepared in Estonia. However, it was launched only in 2010, and the authors intended to ascertain the values of the heads of preschool child care institutions, teachers and parents as well as their conception of value education. The national programme was updated as "Values Development in Estonian Society 20152020" (Ministry of Education and Research 2015). In 2015, the researchers aimed to investigate if and how values of teachers of child care institutions and their conception of value education had changed. The sample in 2010 included nine respondents related to preschool child care institutions: three heads, three teachers, and three parents. The 2015 sample included 10 teachers. The research was conducted by using a qualitative method, which included semi-structured interviews and video observations of activities that teachers carried out with children. In 2010 and 2015, the values were said to be incorporated in general curricular goals and topics of the year. In 2010, the teachers said that values were not separately designated in the kindergarten curriculum; however, they were incorporated into the curriculum. They did not teach values as a separate discipline; values were highlighted in various activities and situation games. In 2015, it was mentioned that value education was consciously included in activities proceeding from the relevant schooling and education domain and the topic of the week. It may be said that in 2010 value education related topics had not been sufficiently introduced in kindergartens yet. Based on interviews and video observations conducted in 2015, it could be claimed that educators would benefit from a more deliberate approach to value education.
\end{abstract}

Keywords: values, value education, preschool child care institution, learning and upbringing methods.

\section{Introduction}

UNESCO Roadmap for implementing the Global Action Programme on Education for Sustainable Development (2014, p. 8) states, "To create a world that is more just, peaceful and sustainable, all individuals and societies must be equipped and empowered 
by knowledge, skills and values as well as be instilled with a heightened awareness to drive such change, and this is where education has a critical role to play". Tilbury and Mulà $(2009$, p. 4) maintain that education for sustainable development (ESD) is a process that people can learn to live in sustainable way. People's values, worldviews, knowledge and creativity are central to sustainable development that is linked to culture (Tilbury \& Mulà, 2009, p. 2). Human dignity, fundamental freedom, human rights, equity, and care for the environment have been important values through the history of the UN. Sustainable development considers it important to pass these values to the future generations (UNESCO, 2012).

Tilbury $(2011$, p. 8$)$ notes that learning is often understood as gaining values and knowledge related to sustainable development; however, ESD learning also refers to learning that clarifies one's own values. Therefore, it is especially important to devote attention to value education in educational institutions. For a systematic implementation of value education in educational institutions, the national programme "Values Development in Estonian Society 2009-2013" (Ministry of Education and Research, 2009) was prepared in Estonia. The national programme was updated as "Values Development in Estonian Society 2015-2020" (Ministry of Education and Research, 2015). Value education is the basis of education for sustainable development. It is necessary to devote attention to values as the main goal of education (Świtała, 2015).

The authors of the present study intended to ascertain the values of the heads of preschool child care institutions, teachers and parents as well as their conception of value education. In Estonian preschool child care institutions, the age of children varies from 1.5 to 7 years. In official documents, the term "preschool childcare institution" (koolieelne lasteasutus) is used, but in practice the term "kindergarten" (lasteaed) is more common in Estonia.

\section{Values and Value Education}

Values make up the heart of culture that carries certain preferences. Dipping into the value system, members of culture know how to orientate in the surrounding reality and evaluate what is good or bad, beautiful or ugly, smart or unwise, etc. Acquisition of the value system characteristic of the respective culture begins in early childhood when behavioural standards are learnt through doing and experiencing (Roots, 2005). Values may be formulated in a number of ways; for example, Rokeach $(1973$, p. 5) defines values as beliefs according to which acting or existing in a certain way is socially or personally better than doing so in an opposite manner. According to Schwartz (1992, p. 6), values represent criteria used by people to choose and justify their behaviours and valuate other people, themselves, and events. A child is born without behavioural stereotypes. Behaviour patterns start to emerge as affected by the surrounding environment and based on personal experience, and rest on the outcomes of different activities, regardless of whether such outcomes are positive or negative (Bandura, 2000, p. 31).

Value education takes place both explicitly and implicitly (Thornberg, 2016). Values are embedded in educational practices, they do not exist isolated, but rather form an entangled element in educational work (Puroila et al. 2016). Explicit value education is written in curricula, i.e., how to teach values, inclusive intentions of teachers and practices. Implicit value education is expressed in a hidden curriculum and in everyday practices (Thornberg, 2016). Value education in a more narrow sense is a planned activity enabling 
the teaching of how to think analytically about values and allowing for moral development. In a broader sense, value education can be seen as any activity which supports personal development. Moral development is closely linked to mental, social, and emotional maturity (Schihalejev, 2011). Contemporary preschool education values contribute to multifold development of a child. It can be said that value education is part of integral development of a human being and teachers as transmitters of knowledge have an important and responsible role in this process. As professionals, teachers are expected to foster high moral beliefs and self-reflection skills. A teacher sets an example with their entire person as an integral whole, i.e., it is important for the teacher to keep an eye on their communication behaviour, activities, and values. The Estonian national curriculum for preschool child care institutions (Government of the Republic, 2008) prescribes as its general goal versatile and consistent development of the child in cooperation with the home and the child care institution. The educational institution should be agreed on common universal values accepted by parents, teachers and children. Agreed values are then transferred to the pedagogical process. In many cases, people have very different attitudes and values; however, certain arrangements should be made in each educational institution. This is especially important during the pre-school age (Šwitala, 2015). Incorporating the above-mentioned goals in studies, child related values, such as consideration of the individual characteristics of each child, creation of a supportive environment, provision of options, and involvement of the child in activity planning, are introduced. The highlighted implementation principles of schooling and education include promotion of a child's individuality, creativity, sense of security, and success related experience, learning through play, valuation of humane and democratic relations, health maintenance and promotion, cooperation between homes and the child care institution, and consideration of specific features of both Estonian and foreign cultures. It may be stated that in shaping value judgments, a child is influenced in a broader sense by the entire cultural environment surrounding them; in a narrower sense, the surrounding material and everyday atmosphere with the people in it as well as relationships between them have an influence on the child. While before the teacher was assumed to play the main active role in shaping values in preschool education, today it is emphasised that a child's experience expands in the surrounding environment, social contact, and active engagement (Hujala, 2001; Lickona, Schaps, \& Lewis, 2007).

\section{Methods of Value Education}

In a preschool institution, various schooling and educational methods can be used to acquire values, most of which are closely related to listening and use of speech. Group meetings and involvement of children in philosophising sessions are suitable methods to develop thinking and deliberation skills. Group meetings provide an opportunity to discuss conflicts while encouraging social communication. The whole group can engage in the discussion and joint problem solving. Children may be allowed to vote so as to ascertain their preferences. Group meetings allow for an expression of emotions and teach one to listen to the speaker (Branscombe et al., 2014, p. 141). Children are active participants in philosophical discussions and they have the opportunity to guide the current topic or issue in a direction they are interested in. Philosophising teaches children how to think critically and creatively, how to respect their companions' ideas and be more tolerant towards differing opinions. The teacher's task is to keep the discussion 
within certain boundaries and show respect for the children's opinions (Gaut \& Gaut, 2015, pp. 8-9). An excellent tool in discussing and construing values is the concept map in which a concept or value is written in a central position and participants attempt to elucidate the concept or value from different angles. The concept map helps children to understand abstract concepts (Nugin, 2013).

Proverbs and old sayings are a favourable tool in teaching values as they are short, didactical, and easily remembered. Folk tales are valuable due to their innate dramatism and the tension which emerges in the comparison of smaller/bigger, stronger/weaker, allowing children to identify with a character. Children's literature, especially if read over a longer period of time in the form of a serial, is an excellent means in shaping value judgments through expanding one's world view (Müürsepp, 2010). Teaching one to understand a person's inner struggle, fairy tales allow for more fruitful learning for children as compared to other types of literary works. Through the story of a fairy tale, advantages of moral behaviour are highlighted as relevant and meaningful for a child. Fairy tales give recommendations in a symbolic format and influence a child's moral beliefs. In fairy tales, right and wrong are clearly contrasted and as this polarisation also occurs in child's mind it provides for a better understanding of the difference between the two (Bettelheim, 2007, pp. 11-12). Favourable tools for communication advancement include role play and various discussions on hypothetical issues, short dramatisations, observation of the behaviour of others and provision of behavioural models in everyday life. Dramatisations should be complemented by discussion and evaluation with additional explanatory comments by an adult on relevant behaviours (Hallap \& Padrik, 2008, p. 24).

Social play as a positive constructive joint activity enables the children to observe their peers, imitate them, negotiate, and compare a companion's behaviour to their own. Through cooperation, children develop a shared understanding of the purpose and course of a game, thus developing their problem-solving skills (Ramani \& Brownell, 2014).

An auspicious method of communicating values is outdoor learning. Tuuling (2013) notes that outdoor learning serves well the attainment of the objectives of any subject field. Outdoor learning also provides for the shaping of social skills as outdoor relations are played out more visibly, enabling children to be more open and reveal their true nature by showing certain characteristics such as helpfulness. Outdoor learning also enables children to get to know each other better, achieve a joyous and close relationship with their peers, and engage in collaboration. Outdoor learning provides for environmentfriendly behavioural habits and supports interest in nature. May (2011, p. 50) claims that studying outdoors, children are less restricted and more independent. Employing outdoor learning activities enables children to develop greater trust for one another. Creative art activities give children a great opportunity to express their feelings and develop a prosocial atmosphere where linguistic skills do not need always be employed. Children that like doing an activity together will join forces again in a different situation. A joint activity such as the above develops a sense of unity in a group (Kostelnik, Soderman \& Whiren, 2011, p. 253).

Different values are present in everyday interaction in kindergartens, even when teachers are not aware of the transmitted values (Puroila et al., 2016). Halstead (1996, p. 12) notes that a large part of values are transmitted via the so-called hidden curriculum. A systematic debate over values is required since children can learn the values randomly. In this case, children learn different values from what teachers were planning to teach. 


\section{Objective}

For systematic implementation of value education in educational institutions, the national program "Values Development in Estonian Society 2009-2013 (Ministry of Education and Research, 2009) was prepared in Estonia. However, it was launched only in 2010, and the authors intended to ascertain the values of the heads of preschool child care institutions, teachers and parents as well as their conception of value education. It was planned to learn how value education was undertaken in kindergartens, how cooperation with parents was organised in terms of value education, and what kind of support was required to administer value education (training, books, information materials etc.). In 2015, the researchers aimed to examine if and how values of teachers of child care institutions and their conception of value education had changed. Furthermore, the researchers intended to ascertain if the teachers' opinions could be applied in practice. The 2015 study looked at teachers specifically as kindergarten teachers who were directly responsible for schooling and education in a kindergarten group.

\section{Research methodology}

The research methodology in 2010 and 2015 was a semi-structured interview (Laherand, 2008; Turner, 2010) and in 2015 - also video observation of schooling and education implemented by teachers. The transcript of all interviews was prepared, the content analysis method was used to analyse the interviews and videos, by grouping the text into categories based on its content, as well as coding was applied to combine the data according to themes (Laherand, 2008; Taylor \& Gibbs, 2010). To ensure respondents' anonymity, names were not used and replaced by designations such as Head 1 first head, Teacher 2 - second teacher, Parent 3 - third parent. All of the interviewees were given the same questions. In 2015, six questions were added to the original questionnaire (Tammik, 2016). In 2010, 319 minutes and 35 seconds of interviews were recorded. Interviews conducted in 2015 amounted to 155 minutes. Video observations were recorded as lasting for a total of 240 minutes. Before the study was conducted, authorisation was gained from heads of the kindergartens and teachers that participated in the study. Consent for video recording was gained from the parents of all of the participating children after the objective of the study as well as the applied confidentiality requirements were explained to them. Both the teachers and the parents confirmed their consent by providing a signature.

\section{Sample}

The sample in 2010 included nine respondents related to preschool child care institutions; three heads, three teachers, and three parents. All of the interviewed kindergarten heads were graduates and had headed a child care institution for 5-8 years. All of the heads had previously worked as teachers with 20-35 years of experience in the area of education. Two teachers had worked in the area of education for 31 years, and one for 10 years. Two teachers had completed secondary specialized education; one teacher had completed higher education. The parents were 26-32 years old; one parent completed basic education, one did not finished basic education, and one was a graduate. All of the respondents in the 2010 study were from kindergartens in Tallinn, both Estonian speaking and Russian speaking institutions. The 2015 sample included 10 teachers from 
two Estonian speaking kindergartens. One of the kindergartens was located in a small town, and the other - in a rural area. The teachers were $27-58$ years old and had worked at a kindergarten for 4-35 years. Five teachers were graduates, one was in the process of completing higher education, and four teachers completed secondary specialised education. All of the study participants were women in 2010 and 2015. Respondents were selected based on availability and willingness to participate in the interview.

\section{Results}

\section{Results of Interviews Conducted in 2010}

\section{Interviews with Heads of Child Care Institutions}

\section{Personal Values}

First, based on the interviews, personal values of the heads were ascertained which included honesty, respect, trust, caring, gratitude, humanity, love, openness, noticing and helping, as well as recognition. The heads also valued family, children, health, and work-related values. One head noted Christian values among her personal values. In their work, the heads proceeded from their own personal values and they saw it important that their personal values coincided with the institution's values.

Head 3 said: "In a bilingual kindergarten, tolerance is especially important; the institution houses both Estonian traditions and Russian culture with their own traditions. I don't care if you're Estonian or Russian speaking. What matters is that you'd be a person in your rightful place."

\section{Common Values and Cooperation}

In a kindergarten, joint values hold a momentously important place. It was discovered that the employees were not always aware of their values.

Head 2 noted: "How do the employees consider basic values? People have never actually thought about what kind of the value they have before we start talking to them."

It is necessary to go over the relevant values within the organisation and review the values from time to time.

Head 3: "We discussed the values we now consider important one more time. What is honesty for us, what is trust for us."

Head 2: "It is important for people that work in a kindergarten to have similar values."

The respondents think that in value education, cooperation with parents is essential. Listed cooperation formats included introduction of the kindergarten house rules, discussions with parents, and joint events. An important role is played by developmental discussions with parents where a teacher ascertains the given family's values. It is most important that the homes share similar values with the kindergarten.

Head 2: "I understand that for the purpose of teaching and educating a child it's necessary for the kindergarten and the parents share the same values. But people are different."

Head 1: "Discussions with parents are a necessity. Discussions are held between two equal parties and do not involve shaking a finger at the parents and telling them that it is because homes are different, have different social and cultural backgrounds, and, also, parents have different educational levels." 


\section{Conception of Value Education}

In value education, the heads see the example of the entire staff as very important; among other things, the heads place importance on their own example; what is important is the organisational culture in place. The heads described value education as follows.

Head 2: "If you love a child, for that child this love represents a value. If a child feels loved, they are happy and will grow into a good person. Children sense it very well if a person working at the kindergarten does not love them."

Head 3: "Value education is an expansive concept, moral education. For children, it is the simplest things - friendliness, kindness, compassion. Helping out a friend who's stuck. Not hurting others. Value education happens in everyday life; the morning meetings that we use, for example, are very nice, they go over all kinds of situations and behaviours, and we jointly discuss the events of the day. The children can also make decisions and choices."

\section{Value Education in Curriculum}

Values form the basis for planning schooling and education in a kindergarten. Values are included in general curricular goals and topics of the year. Value education is not designated as a separate chapter in the kindergarten curriculum. In 2010, the heads were of the opinion that there was not enough material concerning value education. There was a lot of material online; however, it was required for the material to be readily available in the actual kindergarten. It was also thought that parents would be in need of relevant training.

\section{Interviews with Teachers}

\section{Personal Values}

Next, the personal values of teachers were ascertained; such values were honesty, respect, caring, politeness, and health. They also listed home and family, friends, education, and an expensive worldview. The teachers consider the above-mentioned values in their daily work.

Teacher 2: "Your own values at work; your work is shaped, subconsciously considering your own values; all this is automatically embedded in your work."

Teacher 1: "The family, for example - planning my work, parties for example, when I think of the children, I think of their families. Thinking about health - we sing about health; we talk about friendship all the time. What I value in my daily life also traverses to my work."

\section{Common Values and Cooperation}

During the interviews, the teachers also mentioned value conflicts arising when people fostered different beliefs and different value judgments. Teachers are placed in a difficult situation if the teachers say no, yet the parents say yes. The teachers admit that sometimes parents are more difficult than children. Consequently, the teachers stress the importance of cooperation with parents. It is important for the beliefs of all of the parties to be homogeneous. All of the respondents emphasised the role of the developmental discussions in kindergartens where different expectations were talked over. Cooperation is also very important with other employees of the child care institution, i.e., kitchen and cleaning staff, teachers, and management.

Teacher 1 noted: "You won't get anything done alone." 


\section{Conception of Value Education}

What is value education for teachers? Teachers also emphasised the power of setting a good example. Teachers highlighted that values were taught with each activity.

Teacher 1: "It has to be something nice; you have to be good and pay positive things forward to others; all this politeness and that you care about other people, say something nice to them. I give a lot but get much more back. Setting an example is the most important thing in all of the activities of every single day. Value education for a child begins by observing and imitating the teacher. It is ongoing and continuous."

Teacher 2: "I personally have to adhere to the values, which is how I will pass them on. Whoever works at a kindergarten has to set a good example - if the management is proper and diligent it will carry forward to the employees."

Teacher 3: "Values are taught with each activity; it is important to teach the children values such as honesty, respect, love, getting along. The example set by a teacher is most important as children pay a lot of attention to the teacher."

\section{Value Education in Curriculum}

The teachers said that values were not separately designated in the kindergarten curriculum; however, values were incorporated into the curriculum. They did not teach values as a separate discipline; values were highlighted in various activities and situation games. The teachers considered it important to teach the children to have their own opinion and have the courage to voice it. Friendliness, politeness, respect, and sharing skills were also important.

For example, Teacher 2 noted: "Values emerge in weekly plans. So far I haven't really thought of them separately as values. They are just all merged in pleasant communication."

Concerning value education related material, the teachers said that it could be placed somewhere visible where it would be accessible for everyone; there should also be training. In 2010, value education related topics had not been sufficiently introduced in kindergartens yet.

Teacher 2: "At the library I have come across a book on value education but I haven't had the time to read it yet. Hearing about it from you is the first time I have ever heard such a thing exists at all. Right now there's no related material; training is most certainly required."

\section{Interviews with Parents}

\section{Personal Values}

The parents consider honesty, trust, justice, and traditions to be the most important values. The values mentioned also included family values, children, extended family, grandparents, friends, and work related values.

Parent 1: "A person's life is shaped based on the kind of values they have."

Parent 2: "It is important to have time for the children!"

One parent also mentioned material values. Parent 1: "In today's world you cannot forget about material values. At the same time one must understand and recognise that such values are not paramount. It is important to comprehend how a family can cope in the modern world and what the material means are." 


\section{Common Values and Cooperation}

Similar beliefs at home and kindergarten are most important. Parents also find cooperation to be of essential importance. The parents trust their child's teacher. Collaboration with all of the kindergarten's staff is seen as important. All of the parents highlight developmental discussions where values are discussed. Daily communication also plays a significant role.

Parent 3: "The situation is not functional if in one place something is $\mathrm{OK}$ and in another it is not, no matter what we're talking about."

\section{Conception of Value Education}

Parents consider value education foremost as a tool of passing on to their child everything they consider important in life. Parents are of the opinion that values are taught through everyday communication and activities. Furthermore, parents consider that value education is not something you think about every day and they think that value education as such is not administered separately - it is entwined in all other everyday activities. Celebrating holidays and other important dates, teaching traditions, and caring for others are considered important. The example set by the parents also plays an essential role. The parents note that you cannot expect a child to do what the parent is incapable of.

Parent 3: "Small children will imitate their parents; they will do what their parents do."

Parents think that rules have an important place in value education.

Parent 1: "A child must learn that in a group there are certain rules which must be followed; a child must recognise early on that they are but a part - an important part, granted - but yet a part in a large society which is functional only if certain rules are followed by people. To be functional, happy, calm, and successful in the society, a child must learn early on that certain rules must be adhered to in certain groups."

\section{Value Education in Curriculum}

Concerning value education related materials, the parents thought that it would be really good to have smaller discussion groups and that training could also be held at the kindergarten.

\section{Results of Teacher Interviews Conducted in 2015}

\section{Personal Values}

As a result of interview analysis, it became clear that values most frequently listed by teachers included honesty, respect, trust, caring, and tolerance. Some teachers adopted a more expansive view of values, noting that values surrounded and accompanied us throughout our lives.

Teacher 2: "Everything that surrounds us, which is important for a person in daily life, which should be considered when communicating with others or being by yourself."

Family, health, wellbeing, contentment, a sense of duty, friendliness, and valuation of other people are also valued. Listed values also included culture, courage, child-like youthful mentality, justice, benevolence, politeness, cooperation, and health. The teachers noted that they considered values that were important for them in their everyday work, finding this to be normal as consideration for values happening naturally. 
Teacher 4: "I can't really say how I take them into consideration; they are just with me. They are probably part of my character, they just are. It happens naturally."

Consideration of values in everyday work for the teachers consisted in passing the values on to the children while keeping in mind the interests of other people and the surrounding environment. They said values were passed on through the example set by the teacher which was visible through communication.

Teacher 3: "Everything is related to my own communication and attitude. That's how the children get wind of my values; everything I do and think proceeds from my values. Everything I teach the children."

\section{Common Values and Cooperation}

In relation to value education related cooperation with parents, the teachers mentioned communication with parents, meaning provision of explanations and exchange of information. In the case of problematic issues, the teachers thought it necessary to talk to the parents. In a number of cases, the teachers mentioned cooperation with parents through the children. This was connected to giving homework assignments to families in which parents had to do something jointly with their children.

\section{Conception of Value Education}

Value education for the teachers meant teaching children about the right values and good, friendly, and polite relationships. Setting a good example was also highlighted as an important factor in value education. The teachers considered provision of directions and explanations to be necessary in value education so as to deliver the desired message to the children. A safe environment was also mentioned. In some cases, the use of the Free of Bullying methodology and folk traditions was also mentioned. The teachers considered it important that children helped each other in daily activities, especially where older children could assist younger ones. The other mentioned items included the use of didactic children's literature and adherence to group rules, also reminders to children to stick to the rules which, among other things, taught listening skills and taking good care of things. During the interviews, the teachers said that they used the mentioned value education methods consistently on a daily basis. They also mentioned that such methods or a number of the methods were applied as a certain routine.

Teacher 5: "Well, you have this certain routine. Some things have become a sort of a tradition. Things are not all chaotic; every morning we say hello so each morning without exception you come and shake my hand. Children get used to this; not like something is done this way today and in a completely different way tomorrow."

\section{Value Education in Curriculum}

The teachers said they considered value education related goals when planning schooling and education. They mentioned that value education was consciously included in activities proceeding from the relevant schooling and education domain and the topic of the week. Planned inclusion of value education in schooling and education was connected to setting general goals for a week.

Teacher 4: "I haven't really separately inserted value education. It comes along with the general goals and with the objectives of the topic of a class. It is certainly included." 
The teachers' answers to questions concerning value education in relation to the curriculum were rather generally worded, and specific examples were not given, which allowed for the conclusion that value education planning was not thoroughly thought and was incidental in nature.

\section{Results of Observations Conducted in 2015}

\section{Methods of Value Education}

Results of observation analysis indicated that the provision of education mostly focused on providing knowledge in different fields of the schooling and education domain. In the content of schooling and education, value education was included in less than half of the activities. The content of only one activity observed was fully related to value education as proceeding from the Free of Bullying methodology. One activity could be looked at as an activity which valued cultural traditions, and one activity promoting environment-friendly thinking and a caring attitude towards animals were observed as part of the relevant schooling and education activity. In one activity, friendliness as an important value was covered. As the activity was undertaken with very young children, the teacher repeatedly emphasised friendliness and friendly relationships and a related longer discussion was not conducted; rather, the relevant value was highlighted through graphic activity.

Teacher 7: "The glove was broken. And the animals were very sad. What do you think - did the Cuddly Bear mean to break the glove? No be didn't. It was all an accident. They just wanted to live together in the glove as friends. But the animals were smart. They went to see Nana and asked Nana to knit a larger glove for them. And Nana was very friendly and knit them a new glove."

One teacher's activity was conducted in the format of outdoor learning. Children's independent activity was present in half of the activities but for short periods of time on each occasion. Within the framework of independent activity, the teacher gave the children a certain task. On a few occasions, the task was to observe the weather. A few times, the observation involved manual activity where the children had the opportunity to take an independent action. Learning through play was present in less than half of the observed occasions and in all such occasions the children had to engage in an educational game organised by the teacher, which normally took place as a perpetuating activity at the end of the schooling and education activity. Dramatisation was used on a couple of occasions, in both cases as performed by the teacher. In both cases, dramatisation was not followed by a discussion but by a manual activity. The discussion format was used in a few of the activities observed, with a couple of such occasions involving discussions related to value education. Discussions implemented with children in older groups were long and thorough, and all of the children had the opportunity to express their opinion. Children's literature and folk tales were used on a few occasions. Counting rhymes, riddles, folk customs, and fairy tales were also used.

The individual characteristics of each child were considered by a few teachers when the group contained children with another language spoken at home, children with special needs, or children with a need for a greater sense of safety. The assignment was repeated for children with another first language and such children were given ample time to express themselves calmly. The child with a special need sought out contact with the teacher by staying close to the teacher. The teacher stroke the child's back during the activity, thus calming the child. The child who required a stronger sense of safety 
was given the opportunity to stay close to the teacher during the observed activity. Other factors considered when arranging schooling and education included the age of the children as most groups consisted of children of different ages. The shaping of a sense of unity was evident in a number of observed activities. In some of the cases, the activity started by the children holding hands in a circle and reciting a previously learned counting rhyme or singing along with the teacher. Singing the names of all the group's children and staff in "Kes on täna meiega" (Who's with us today) helped establish a sense of unity and give value to each individual person. A sense of unity was also enforced by the children and the teacher all wearing uniform costumes during an activity. Using the same materials - the purple bear within the Free of Bullying methodology - and giving each other massages ensured a unified group feeling. Listening skills were paid attention to in more than half of the activities. The children had to listen carefully to a story read out or a dramatisation enacted by the teacher. The teachers repeatedly directed the children's attention to the skills of listening to one another in discussions; for example:

Teacher 8: "And you will make your ears listen very carefully to find out what was said and what you should remember. Was there anything related to good manners and values?"

Forming cooperation skills was evident in less than half of the activities and the teacher gave the children options to choose from in a few activities only. There were next to no activities providing for an experience of success. This was probably due to the fact that children's long-term independent activity which would result in a success experience was also scarce in the observed activity. Success experiences and joy could be observed in group activities and manual activities. Activities presenting folk traditions also delivered joy, fun, and excitement. Manual activities provided children with the opportunity to experience the joy of creative expression.

\section{Discussion}

In conclusion, it can be said that participants in the 2010 and 2015 studies had similar personal values. The values mentioned most times were honesty, respect, caring, trust, health, family, and traditions. Similar results were gained in the study by Ülavere and Veisson (2015a) where Schwartz's research methodology was used to ascertain the personal values of heads of preschool child care institutions, teachers, and parents. All of the groups gave the highest scores to the values of caring and trustworthiness, while in Ülavere and Veisson's study (2015a) the value of tradition also received a rather high score.

Work related values were also highlighted; both the teachers and the heads claimed to consider their personal values in their everyday work with such consideration consisting in passing said values on to the children, while keeping in mind the interests of other people and the surrounding environment. The teachers said during the interview that consideration of values important for them in planning schooling and education was oftentimes natural and spontaneous. This was also confirmed by most of the observed education activities as well as the set goals, which did not involve pre-planned value education. Other authors also stressed the same findings, declaring that a large part of value education was undertaken through the so-called hidden curriculum and, consequently, awareness of values children were actually learning was low(Halstead, 1996; Puroila et al. 2016; Thornberg, 2008). 
During an activity, some teachers could be observed doing things mentioned in the interview. A teacher who listed folk traditions as a value important for her also conducted teaching activities employing folk traditions. A teacher who emphasised friendly relationships in value education involved the same value in applied teaching/learning activities. Value education was mostly defined as passing on the right values such as honesty, respect, love, good and friendly relationships, and politeness; it is important to pass on values that are personally considered as important. Ülavere and Veisson' study (2015b) yielded similar results where heads of preschool child care institutions, teachers, and parents considered the most important values to be passed on to children to be honesty, health, helpfulness, cooperativeness, tolerance, the sense of duty, and trust.

The teachers consider it important to teach the children to have their own opinion and have the courage to voice it. It was highlighted that values were taught in the course of every activity, value education began for a child by observing and imitating the teacher and constituted a continuous process. Bandura's (1977) social learning theory states that most of people's behaviours, attitudes, and values are learned by observing a role model. In value education, the example set by the entire staff is important in preschool child care institutions, including the example of the heads of child care institutions, the culture of the entire organisation. The parent's example also plays a vital role. The parents note that you cannot expect a child to do what the parents are incapable of.

Values are taught through everyday communication and activities. It was mentioned that value education as such was not administered separately but, rather, included in all other daily activities. Celebrating holidays and other important dates, teaching traditions, and caring for others were considered important. In value education, parents considered rules to also have an important place as well as mentioned adherence to the group's rules as an important aspect in passing on values. The same results were gained in Ülavere and Veisson' study (2015b) which ascertained the methods used to administer value education in preschool child care institutions in Estonia. The heads, teachers, and parents alike think that values are passed on to children foremost through group rules and good manners, during daily communication and activity with personal example occupying a vital role.

The respondents thought cooperation with parents was essential to value education. Suur (2014) also stresses the importance of cooperation with parents. Suur notes that the child care institution and parents need to cooperate, and parents need to communicate among themselves. Parents are increasingly more involved in the daily life of the child care institution and parents have the right and obligation to make decisions in issues involving their children (Suur, 2014). Listed cooperation formats foremost included discussions with parents and joint events. An important place is held by developmental discussions with parents where the teacher ascertains the family's values as well as relevant similar and differing aspects. It is very important that the kindergarten and the home share similar values (Šwitala, 2015). During the interviews, the teachers also mentioned value conflicts arising when people fostered different beliefs and different value judgments.

The value education methods included explaining, philosophising with children, use of children's literature, folk traditions, cultural traditions, outdoor learning, dramatisations, manual activities, and drawing of attention to helping one another. Results of a study conducted in Swedish kindergartens in 2001 (Johansson, 2002) indicated that 
local teachers devoted a lot of attention to moral issues, listing as important consideration for each other, caring and compassion, consideration for another child's things, and waiting for one's turn. Most efforts by Swedish teachers were placed in influencing the children. In the current study, the teachers also endeavoured to influence the children through personal example, employing explanations and guidance. Chats, discussions, and situation games were also mentioned as tools presumably enabling the shaping of critical thinking. The teachers exhibited uncertainty in answering questions related to the curriculum. Results of the present research confirmed the results of the study conducted in 2002-2003 in preschool child care institutions in Helsinki and Tallinn (Ojala \& Talts, 2009) where it was discovered that in Estonian kindergartens less attention was paid to ethical education than in Finland and special attention was devoted to knowledge related to specific domains of relevant schooling and education.

Planning of value education related activities was at times spontaneous, even though allegedly such education is considered beforehand. Methods highlighted as used in value education included chats, discussions, and use of proverbs. During the observed activities, however, a discussion was employed only a few times. Proverbs were not used; however, riddles were presented to the children. In passing on values in 2015, kindergartens employed the Free of Bullying methodology, which was harnessed in schooling and education by teachers. While interviews indicated that teachers implemented value education more through content, observations revealed that such education was more involved in the organisational side of schooling and education. It is possible that planning education activities, value education was not directly considered and, rather, selected methods were used to render activities more versatile and exciting. The teachers highlighted a personal example in passing on values. Based on observations, it may be said that during relevant activities all of the teachers were respectful, polite, and friendly in their communication with children. Some teachers said in the interview that value education related topics were applied through the topic considered. The observed activities indicated that value education related topics of the week or education activity connected topics simplified the administration of such education. Values form the grounds for planning schooling and education in a kindergarten. In 2010 and 2015, it was stated that values were incorporated in general curricular goals and in the topics of the year. In 2010, the teachers said that value education was not separately designated in the kindergarten curriculum; however, values were incorporated into the curriculum. They did not teach values as a separate discipline; values were highlighted in various activities and situation games. In 2015, it was mentioned that value education was consciously included in activities proceeding from the relevant schooling and education domain and the topic of the week. Planned inclusion of value education in schooling and education in connection to setting general goals for a week was also highlighted. Observation results allowed stating that in the provision of education, most emphasis was placed on providing knowledge related to specific domains of relevant schooling and education; however, in implementing schooling and education, teachers also placed importance on considering the individual characteristics of each child, considering children with special needs, developing listening and cooperation skills, and making sure that the activities resulted in success experiences, joy, fun, and excitement.

Concerning value education related material, the teachers said in 2010 that it could be placed somewhere visible where it would be accessible for everyone; there should 
also be training. It might be stated that in 2010 value education related topics had not been sufficiently introduced in kindergartens yet. Based on interviews and video observations conducted in 2015, it could be claimed that educators would benefit from a more deliberate approach to value education.

\section{Conclusion}

In value education, a role model of the entire kindergarten' staff is very important. The culture of organisation is influenced by individual examples of heads. Teachers and parents also emphasise the power of setting up a good example. Teachers highlight that values are taught with each activity and the parents note that you cannot expect a child to do what the parents are incapable of. Value education begins for a child by observing and imitating the adult constituting a continuous process. Values are taught through everyday communication and activities. Value education as such is not administered separately but rather included in all other daily activities. Teachers do not teach values as a separate discipline, but they are highlighted via various activities. It is necessary to recognise that value education takes place both explicitly and implicitly and values are embedded in educational practices. It is also important that children actually gain experiences. If we want that our children grow up caring, they have to experience that someone cares about them. Child's experience expands in the surrounding environment, in social contact and through active engagement. Kindergarten and home must share similar values and cooperation with parents is essential in value education. Based on the results of the present study, it can be claimed that educators would benefit from a more deliberate approach to value education.

\section{References}

Bandura, A. (1977). Social learning theory. Englewood Cliffs, NJ: Prentice-Hall. Бандура, А. (2000). Теория социального научения [Social Learning Theory]. СанктПетербург: Евразия.

Bettelheim, B. (2007). Muinasjuttude võlujõud: muinasjuttude tähtsus ja tähendus [Fairy Tales Magic: Meaning and Importance of Fairy Tales]. Tartu: Atlex.

Branscombe, N. A., Burcham, J.G., Castle, K., Surbeck, E., Dorsey, E., \& Taylor, B. (2014). Early childhood curriculum: A constructivist perspective. New York; London: Routledge.

Gaut, B., \& Gaut, M. (2015). Filosoofilised arutelud väikeste lastega: praktiline käsiraamat õpetajale [Philosophical Discussions with Small Children: A Practical Manual for Teachers]. Tartu: Kirjastus Studium.

Government of the Republic. (2008). Estonian National Curriculum for Pre-school Child Care Institutions. Riigi Teataja I, 23, 152.

Hallap, M., \& Padrik, M. (2008). Lapse kõnearendamine [A Child's Speech Development]. Tartu: Tartu Ülikooli Kirjastus.

Halstead, J. M. (1996). Values and values education in schools. In J.M. Halstead and M.J. Taylor (Eds.), Values in Education and Education in Values (pp. 3-14). London: The Falmer Press. 
Hujala, E. (2001). The curriculum for early learning in the context of the society. In H. Kukemelk, K. Karlep, E. Krull, J. Mikk, E. Pilli, \& K. Transberg (Eds.), Kasvatus ja aated. (pp. 241-248).Tartu: Tartu Ülikooli Kirjastus.

Johansson, E. (2002). Morality in preschool interaction: Teachers' strategies for working with children's morality. Early Child Development and Care, 172(2), 203-221. Retrieved 8 April 2015, from http://www.tandfonline.com.ezproxy.tlu.ee/doi/abs/ 10.1080/03004430210887\#abstract

Kostelnik, M. J., Soderman, A.K., \& Whiren, A.P. (2011). Developmentally appropriate curriculum: Best practices in early childhood education. Upper Saddle River: Pearson Education.

Laherand, M.-L. (2008). Kvalitatiiune uurimisviis [Qualitative Research Method].OÜ Infotrükk.

Lickona,T., Schaps, E., \& Lewis, C. (2007). Eleven Principles of Effective Character Education. Character Education Partnership. Character Education Partnership [In Estonian.Tulemusliku iseloomukasvatuse üksteist printsiipi. Translated Laura Lilles].

May, P. (2011). Child Development in Practice: Responsive Teaching and Learning from Birth to Five. London \& New York: Routledge.

Ministry of Education and Research. (2009). Values Development in Estonian Society 2009-2013. Retrieved 23 May 2015, from http:/www.eetika.ee/sites/default/files/ www_ut/eesti_uhiskonna_vaartusarendus_2009-2013_0.pdf

Ministry of Education and Research. (2015). Values Development in Estonian Society 2015-2020. Renewed programme. Retrieved 22 May 2016, from http://www.eetika. ee/sites/default/files/eetikakeskus/files/v22rtusprogrammi_j2tkuprogramm_20152020.pdf

Müürsepp, M. (2010). Väärtuste kujundamine keele ja kõne õpetamise ja lastekirjanduse kaudu [Values formation of language and speech, and teaching through children's literature]. In M. Veisson (Ed.), Väärtused koolieelses eas: väärtuskasvatus lasteaias [Values Preschool Age: Values Education in Kindergarten] (pp. 27-42). Tartu: Eesti keele Sihtasutus.

Nugin, K. (2013). Keskkonna loomine [Creating an environment]. In K.Nugin (Ed.), Üldõpetuse rakendamine lasteaias [Implementation of General Education in Kindergarten] (pp. 84-96). Tartu: Atlex.

Ojala, M., \& Talts, L. (2009). Preschool achievement in Finland and Estonia: GrossCultural comparison between the cities of Helsinki and Tallinn. In L. Talts (Ed.), Eelkoolihariduse efektiivsus ja selle jätkusuutlik areng põhikoolis (pp. 142-163). Tallinn: Tallinna Ülikooli kirjastus.

Puroila, A.-M., Johansson, E., Estola, E., Emilson, A., Einarsdóttir, J., \& Broström, S. (2016). Interpreting values in the daily practices of Nordic preschools: A crosscultural analysis. International Journal of Early Childhood, 48(2), 141-159. doi: 10.1007/s13158-016-0163-3

Ramani, G.B., \& Brownell, G.A. (2014). Preschoolers cooperative problem solving: Integrating play and problem solving. Journal of Early Childhood Research, 12(1), 92-108. Retrieved 15 April 2015, from http://ezproxy.tlu.ee/login?url=http://search. ebscohost.com/login.aspx? direct=true \&db=edb\&AN=94338606\&site=eds-live

Rokeach, M. (1973). The nature of human values. New York: Free Press; London: Collier-Macmillan. 
Roots, H. (2005). Loenguid organisatsiooniteooriast [Lectures on the Theory of Organisation]. Tallinn: Sisekaitseakadeemia.

Schihalejev, O. (2011). Väärtuskasvatus õpetajakoolituses [Values Education in Teacher Training]. Tartu: Tartu Ülikooli Kirjastus.

Schwartz, S. H. (1992). Universals in the content and structure of values: Theoretical advances and empirical tests in 20 countries. In M. Zanna (Ed.), Advances in Experimental Social Psychology, 25 (pp. 1-65). San Diego, CA: Academic Press Inc.

Suur, S. (2014). Õpetajate, direktorite ja lastevanemate hinnangud koostööle koolieelses lasteasutuses. [Teacher-Principal-Parent Opinions about Cooperation in a Pre-School Child Care Institution] PhD diss. Supervisor prof M.Veisson, Tallinna Ülikool, Kasvatusteaduste Instituut.

Świtała, E. (2015). Values education - A reality or myth in Polish schools. Discourse and Communication for Sustainable Education, 4(1), pp. 57-66. Retrieved 11 May 2017, from doi:10.2478/dcse-2013-0005

Tilbury, D., \& Mulà, I. (2009). Review of Education for Sustainable Development Policies from a Cultural Diversity and Intercultural Dialogue: Gaps and Opportunities for Future Action. Paris: UNESCO. Retrieved 10 May 2017, from http://unesdoc.unesco.org/images/0021/002117/211750e.pdf

Tilbury, D. (2011) Education for Sustainable Development: An Expert Review of Processes and Learning. Paris: UNESCO. Retrieved 10 May 2017, from http://unesdoc. unesco.org/images/0019/001914/191442e.pdf

Tammik, A. (2016). Väärtuskasvatus lasteaias läbi õppekava erinevate õppe- ja kasvatustegevuste [Value Education in Nursery School through Learning and Upbringing Activities of the Curriculum. Master Thesis]. Tallinn: Tallinna Ülikooli Haridusteaduste Instituut.

Taylor, C., \& Gibbs, G. R. (2010). How and what to code. Online QDA Web Site. Retrieved 12 May 2017, from http://onlineqda.hud.ac.uk/Intro_QDA/how_what_ to_code.php

Thornberg, R. (2008). Values education as the daily fostering of school rule. Research in education (Manchester), 80(1), 52-62.

Thornberg, R. (2016). Values education in Nordic preschools: A commentary. International Journal of Early Childhood, 48(2), 241-257. doi: 10.1007/s13158-016-0167-z

Turner, D. W. (2010). Qualitative interview design: A practical guide for novice investigators. The Qualitative Report, 15(3), 754-760. Retrieved 10 May 2017, from http://nsuworks.nova.edu/tqr/vol15/iss3/19

Tuuling, L. (2013). Õuesõpe-lõimitud aktiivse õppimise parim viis [Outdoor educationintegrated active learning in the best way]. In K. Nugin (Ed.), Üldõpetuse rakendamine lasteaias [Implementation of General Education in Kindergarten]. (pp. 97121).Tartu: Atlex.

UNESCO (United Nations Educational Scientific and Cultural Organisation). (2012). Learning and Training Tools. Paris: United Nations Educational, Scientific and Cultural Organisation. Retrieved 11 May 2017, from http://unesdoc.unesco.org/ images/0021/002163/216383e.pdfUNESCO (United Nations Educational, Scientific and Cultural Organisation). (2014). Roadmap for Implementing the Global Action Programme on Education for Sustainable Development. Paris: United Nations Educational, Scientific and Cultural Organisation. Retrieved 11 May 2017, from 
http://unesdoc.unesco.org/images/0023/002305/230514e.pdf

Ülavere, P., \& Veisson, M. (2015a). The values of Estonian preschool childcare institutions' principals, teachers, and parents. The European Journal of Social and Behavioural Sciences, 13(2), 1791-1799. doi:10.15405/ejsbs.160

Ülavere, P., \& Veisson, M. (2015b). Values and values education in Estonian preschool child care institutions. Journal of Teacher Education for Sustainability, 17(2), 108124. doi: 10.1515/jtes-2015-0014

Correspondence concerning this paper should be addressed to Pärje Ülavere, Tallinn University, Narva mnt 25, 10120 Tallinn, Estonia. Email: parjeulavere@gmail.com 